Original Paper http://ajol.info/index.php/ijbcs http://indexmedicus.afro.who.int

\title{
The use of traditional ecological knowledge in sustainable use and management of plant resource through a community-based and participatory assessment
}

\author{
Nicole Marie GUEDJE ${ }^{1 *}$, Fulbert TADJOUTEU ${ }^{2}$, Nicodeme TCHAMOU ${ }^{3}$ and \\ Ousseynou NDOYE ${ }^{4}$ \\ ${ }^{I}$ Department of Pharmacognosy and Pharmaceutical Chemistry, Faculty of Medicine and Biomedical \\ Sciences, University of Yaounde 1, Cameroon. \\ ${ }^{2}$ National Herbarium of Cameroon - Institute of Agricultural Research for Development (IRAD); PO \\ Box 1601 Yaoundé-Cameroon. \\ ${ }^{3}$ USAID/CARPE, 198 Avenue Isiro, Kinshasa Gombe, Democratic Republic of Congo. \\ ${ }^{4}$ Food and Agriculture Organization of the United Nations (FAO), Sub-regional Office for Central Africa, \\ P.O Box 2643 Libreville, Gabon. \\ ${ }^{*}$ Corresponding author; E-mail: manigue@hotmail.com; Phone: + 237676075355
}

\section{ACKNOWLEDGMENTS} research.

We are indebted to the Ministry of Higher Education (MINESUP) of Cameroon, for funding this

\begin{abstract}
This study was carried out on a community-based and participatory field-based experiment, combining traditional ecological knowledge (TEK) and scientific knowledge, with the aim of defining criteria for sustainable harvest prescriptions for Garcinia lucida bark, focusing on its profitability, acceptability and ecological sustainability. Bark harvesting process was documented by monitoring 35 bark gatherers, who have provided accurate information on habitat, density, recruitment, seed predator of G. lucida species that matched well information found with ecological studies. TEK have provided useful information on the species geographical distribution that could serve as important tools in resource mapping and management. Based on the harvest practices experimental records and using TEK, bark gatherers have recommended a strip of $1 / 3$ or $2 / 3$ of tree circumference, by peeling off bark using machete, for household consumption; or ring-barked or felling trees for commercial proposes; a selection of larger trees and a repeat harvest on the same tree after complete bark recovery. Few gatherers, who started planting G. lucida in their coco-farm, showed real interest in applying these harvest prescriptions. However, the open-access status of wild stands constituted the most vulnerable point in applying these prescriptions. This study results have direct bearing on attempts towards sustainable resource use and adaptive management incorporating current ecological knowledge into participatory forest and resource management planning and regulations.
\end{abstract}

(C) 2017 International Formulae Group. All rights reserved.

Keywords: Garcinia lucida bark, multiple-used plant species, traditional ecological knowledge, sustainable harvesting, community-based and participatory management. 


\section{INTRODUCTION}

Bark is one of the most important plant parts used as raw material in traditional medicine worldwide, as well as in urbanindustrial societies (Cunningham, 2014a; Senkoro et al., 2014; Mariot et al., 2014). Bark is also the most commonly extracted plant parts for biological activity tests in laboratories (Cunningham, 2014a; Kemppainen et al., 2014). Consequently, the processing and trade of bark have become an important source of income (Romero et al., 2014; Cunningham, 2014b; Ingram et al., 2015). Unfortunately, the increased trade and processing of bark has shifted from subsistence use to large-scale commercial use, posing a threat to supply of raw material and species conservation, either to traditional practitioners and to pharmaceutical laboratories. High exploitation level as well as high market values of bark had led to high exploitation pressure, and extractive systems with little regard for the continued supplies and regeneration of the exploited species, giving rise to many concerns related to overharvesting and resource depletion, sometimes leading to species population extinction (Peters, 1996; Geldenhuys, 2011; Baldauf and dos Santos, 2014; Romero et al., 2014; Pandey, 2015).

Many studies have been undertaken to develop method for sustainable management of bark stripping (Geldenhuys et al., 2007; Delvaux et al., 2009; Baldauf and dos Santos, 2014; Mariot et al., 2014; Costa et al., 2015; Guedje et al., 2016). However, sustainable exploitation of bark requires an integrated design and monitoring of stripping practices, based on sound biological and socio-economic information (Peters, 1996; Baldauf and dos Santos, 2014). Hence, moving from the ecological sustainability designed to the implementation of the sustainable harvest and management is far from simple. The non- or insufficient involvement of local communities who have a vested interest in managing and conserving the resources that form the basis of their livelihood, often mitigates the success of such management strategies (Persoon, 2006; Baldauf et al., 2015; Chatterjee and Sarkar, 2016). Thereby, the present study was carried out on a community-based and participatory field-based experiment, combining indigenous or traditional ecological knowledge (TEK) and scientific knowledge, with the aim at defining criteria for sustainable harvest prescriptions for the species, focusing on its (i) profitability to yield sufficient bark either for household consumption or trade; (ii) acceptability to be easily passing and applicable by gatherers, and (iii) ecological sustainability, allowing tree survival or with less impact on plant growth and development. The approach was illustrated on Garcinia lucida trees (named "essok" in boulou and ewondo language), a small understory dioecious species, found in high-density stands in the humid Atlantic forests of South Cameroon; widely used in Central and West Africa to treat several diseases, such as poisoning, gastritis, snake bite, gynaecological pains and infections, sexual diseases and cancers, and as additive to palm wine production. Many active compounds with bioactivities such as antibacterial, antimicrobial, anti-inflammatories, antacids, curare antidote or inhibitory effect, $\beta$ lactamase inhibition have been found in its diverse plant parts and summarized by Guedje et al. (2017). Several in vitro and in vivo activities were carried out on G. lucida and found to be potential good sources of 
numerous therapeutic agents (Nguedia and Nsagha, 2014).

\section{MATERIALS AND METHODS}

\section{Study location}

The study was carried out within an area located in the South Cameroonian Atlantic humid forests in the Bipindi Lolodorf - Akom II region, in four main villages specialized in bark harvesting and trade : Nkouékouk, Nyangong, Meka'a II and Mefak villages (Figure 1). The climate is humid tropical with two rainy and two dry seasons, with a yearly rainfall of about 2000 $\mathrm{mm}$, and with an average annual temperature of around $25^{\circ} \mathrm{C}$. Biodiversity in this part of Cameroon ranks among the highest in Africa. The forest cover is still largely intact, but due to anthropic activities, it is alternated with a mosaic of fields, fallow lands, secondary forest, and logged-over forest.

\section{Traditional bark stripping survey}

Field visits with individual and group discussions, together with field observations, were conducted in the main four villages recognized for their intensive bark harvesting and trade. Relevant information concerning traditional ecological knowledge (TEK), bark stripping and processing, as well as the number of people involved in these activities were collected. Questions focusing on natural history observations related to the species ecology have targeted information on species identification, habitat and abundance, optimal growing conditions, regeneration and dispersal. Questions associated with bark stripping have pertained to more specific information on how G. lucida stands were located, criteria to select harvestable trees, stripping practices applied, as well as resource management and conser- vation practices. The answers to these questions were compared with available ecological data derived from previous studies (Guedje et al., 2007, 2016) and field studies conducted in parallel with this survey.

Thereafter, the various stages of the bark harvesting process were documented by monitoring a total of 35 bark harvesters and/or traders ( 8 women and 27 men) for several days each and during a five-month period in the four villages. These harvesters were selected based on their identification as established "essok" gatherers by one or more peers. Walking distances (time) between the trees and the harvesters' homesteads were recorded, as well as the number of sites visited, the number of trees stripped. The quantity or bark wet mass harvested was then weighed using a Salter $100 \mathrm{~kg}$ hanging scale. Data collected were statistically analysed through partial correlation test (Newman test) with Statistical Package for the Social Sciences (SPSS, Inc., Chicago, IL, USA).

\section{Experimental bark stripping assessment}

The following treatments, illustrating the traditional bark stripping practices, were applied:

(i) Control (C) : no debarking;

(ii) Partial debarking of the stem, with three sub-treatments: (a) peeling off pieces of bark with a machete and debarking over $1 / 3$ of the tree circumference at breast height (P 1/3), (b) hammering on the tree with a stick and debarking over $1 / 3$ of the tree circumference at breast height (H 1/3), and (c) hammering with a stick and debarking over $2 / 3$ of the tree circumference at breast height ( $\mathbf{H}$ 2/3);

(iii) Ring-barking of the stem (R 3/3 ); 
(iv) Felling the tree at approximately $1 \mathrm{~m}$ height above the ground and thereafter harvesting the bark on the felled tree part $(\mathbf{F})$.

For each treatment (harvest method) and each sub-treatment, 20 healthy trees (no scars and previous bark harvest) were selected, marked with numbers, equally distributed in two size classes : [10 - 17[ cm diameter at breast height $(\mathrm{DBH})$ for small trees and [17 - 26[ cm DBH for large trees. The sample was restricted to this number of trees and size classes as healthy trees were scarce, and as many G. lucida forest stands in the area mostly composed of harvested trees or unharvested trees but covered with many scars. Later, over the two-year study period, 16 trees $(13.33 \%)$ were illegally stripped by unknown local community members and struck out from the sample.

Bark was extracted from $0.3 \mathrm{~m}$ from the ground (or above stilt roots) in a vertical strip up to $1.5 \mathrm{~m}$ stem height, by harvesters organized in working-groups of five individuals each. For each treated tree, "bark easiness" to be removed from wood like "cassava peel", or "bark hardness" to be removed from wood were noted by each working-group. Health parameters (survival, sprouting, bark re-growth, stilt-root development) were monitored every month over a period of two years. Insect holes were noted, new sprouts and shoots around the wound were counted and re-growth of bark was monitored, and at 6,12 and 24 months.

\section{Community-based and participatory set-up of sustainable bark harvesting criteria}

The processes implemented together with local communities and bark harvesters included the following steps:
- Organization of meetings at Nkouékouk and Mefak villages, presentation of Garcinia lucida research project, discussions related to the uses and importance of "essok" at the village level, as well as to the local people perceptions concerning the notion of sustainable use and management of wild resources;

- Appointment by the entire community of two working groups composed of five harvesters in each village. Assignment to each group the task of inspecting and evaluation of the experimental bark stripping assessment described above;

- Jointly definition and design of criteria for an efficient and sustainable bark stripping system, based on the results of the bark stripping experiment and using their knowledge about the species ecology or biology;

- Testing the effectiveness and appropriateness of the designed bark stripping system by each harvester and each working-group, and round discussions and exchanges within all the groups to draw out synthesis and recommendations;

- Meetings with the entire community in each village, to restitute the process and to inform about the sustained bark stripping system jointly defined by group members; finally, round discussions to amend and improve the bark stripping system set up, as well as to inform others villages of the region about the project results. 


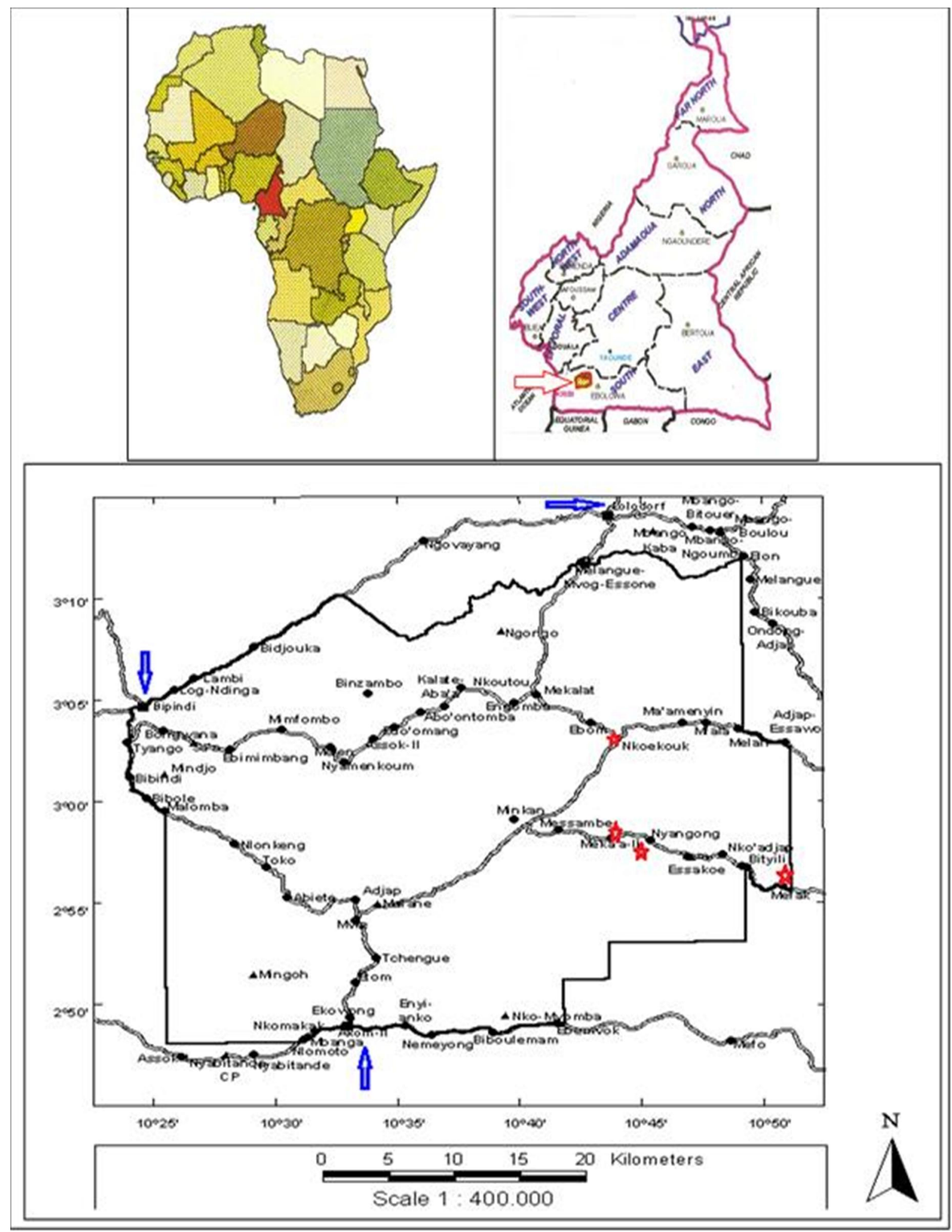

Figure 1: Map of the Bipindi - Lolodorf - Akom II region (South Cameroon) showing study villages ( 


\section{RESULTS}

\section{Traditional ecological knowledge of essok} gathering

The traditional ecological knowledge (TEK) on "essok", including local management practices, defined based on harvesters answers are summarized in Table 1. All harvesters were familiar with "essok", but thought that there were two types of G. lucida species, one which bark was easily detached from the wood and other which bark was hardly removed from the wood. On the contrary, TEK of "essok" habitats, density, recruitment, seed predator/dispersal matches well the information found with ecological studies carried out in parallel with this community-based and participatory assessment. However, there were gaps concerning species phenology and pollination. Almost all the harvesters had excellent knowledge about $G$. lucida stand geographical distribution in the region, mostly located during their hunting trips and they were able to indicate and locate many "essok" stands. In that sense, TEK provided information more efficiently in "essok" stand locations than the use of transects. They have clearly indicated areas where "essok" trees occur in the Bipindi-Lolodorf-Akom II region and equally where the species did not occurs, like the area of Ebimimbang (near Bipindi), where inventories with transects and plots of 1 ha did not allow to found G. lucida trees.

Harvesters have developed from their history of harvesting, TEK related to bark stripping, resource management and conservation practices. They applied criteria to select sites based first on distance to village and second on the occurrence of abundant and larges trees. The criteria for harvestable trees were first by based on bark thickness and second by on the ability on trees to be easily peeled. Where over-exploitation of large trees occurs, they shifted to trees with smaller diameter at breast height $(\mathrm{DBH})$ and later to new stand areas. So, they have mentioned that walking distances between stand trees and homesteads were increased (more than 10-20 $\mathrm{km}$ ) due to overharvesting and forest further pressure and impoverishment. They also indicated many abandoned stands because of intensive exploitation carried out two years ago and that has led to resource depletion. They have also pointed out the fact that, due to the increase demands of bark in towns and neighbouring countries (Gabon and Equatorial Guinea), there was conflict resurgent related to tree harvest property rights and G. lucida stand ownership between neighbouring communities. All harvesters were aware that ring-barking or girdling trees led the tree to die, and suggested, as part of the package of actions to reduce pressure on the species, harvesting regulation by protecting young trees, or by temporal or geographical restricting bark stripping. They however mentioned that these rules will be difficult to establish as the open access status of "essok" stands in the region. A major reason given by harvesters in order to support this was that people did not feel responsible for the forest resource protection. Consequently, this resulted in in-opportunistic over-exploitation.

Few other management practices were applied with regard to bark and seeds. The seeds were harvested by simply gathering on the forest soil and were stored for months if there was no insect or larvae inside, while the bark, kept in bags and covered with "essok" leaves to protect them against drying-up, were stored for 2 to 3 weeks. Dried bark and seeds were preserved longer when ground, however, grinding was mostly done for medicinal purposes. Although dried bark was said to be used in palm wine production, it was seldom observed in this region. The commercialization of the powder of bark and seeds was seen at the market of Ebolowa, suggesting that promoting the use of ground bark or seeds bark could lead to a reduction in the amount of bark unsold or perished, and hence the quantity of resource extracted from forest. Some of the harvesters reported that they have started planting "essok" in their coco-farms. The survey revealed that less than $2 \%$ of harvesters in the five villages started to plant Garcinia lucida trees, which was low compared with the number of bark gatherers 
in the region (Figure 2). The applied propagation technique was transplanting wild seedlings or seeds from the forest to cocoaplantations.

Current bark stripping patterns and potential threat to sustainability

Bark harvesting in the BipindiLolodorf-Akom II was generally considered to be very hard work most suitable for strong young men because of the difficulty of walking on about 10 to $20 \mathrm{~km}$ around, climbing hills or mountains exceeding 1400 $\mathrm{m}$, and carrying loads of bark through the humid forest. That explained why not more than $7 \%$ of people were involved in bark commercialization (Figure 2). The time spent to go to G. lucida forest stands which are open-access, to harvest half or one bag of bark and to come back was between 5 to 12 hours; one bag of wet bark weighing on average 45 $\mathrm{kg}$. Collection trips were done by individuals or by group of gatherers and relatives.

The number of areas visited, as well as the number of trees stripped and the mass of bark collected by the 35 harvesters are presented in Table 2. Among the 35 bark gatherers followed, $66 \%$ were bark traders who had stripped a total of 2717 trees and collected $17730 \mathrm{~kg}$ of wet bark (mean, 24 trees/harvester/month; $154 \mathrm{~kg} /$ harvester/ month), while bark harvesting as additive to palm wine production and raw material for medicines at the village-level was done by $34 \%$ of harvesters who have stripped 93 trees and collected $180 \mathrm{~kg}$ of wet bark mass (mean, 2 trees/harvester/month; $3 \mathrm{~kg}$ of bark mass/harvester /month). Statistical analysis shows that the quantity of total bark mass collected was positively correlated with the total number of trees stripped $(\mathrm{r}=0.93 ; \mathrm{p}<$ $0.01)$, the bark harvest frequency $(r=0.69$; $\mathrm{p}<0.01)$ and the number of areas visited and exploited $(\mathrm{r}=0.49 ; \mathrm{p}<0.01)$. This analysis, while expressing the interaction between the type of resource users (harvesters for trade outside the village and collectors for medicine and palm wine for processing at the villagelevel) and the quantities of bark harvested and number of areas exploited, also highlighted the closer link between sound socio-economic and biological information; suggests that these factors may constitute important parameters to take in account when designing and establishing species harvest prescriptions and conservation, as well as highlighting the need of an effective involvement of local communities who have a vested interest in managing and conserving the resources that form the basis of their livelihood.

\section{Emerging criteria for sustainable bark stripping prescriptions and resource management from community-based and participatory assessment}

Arguments discussed during meetings related to local-community perceptions of resource sustainability, together with the experimental bark stripping monitoring and assessment have enabled local gatherers to jointly define the criteria for an efficient and sustainable harvest prescriptions, based on the results of the test and using their knowledge concerning the resource ecology, summarized in Table 1. According to local harvesters, the most appropriate stripping practice was peeling off pieces of bark using a machete on standing trees, instead of hammering the stem with a stick. The sustainable level of bark stripping on standing trees was a partial debarking $(1 / 3$ to $2 / 3)$ of the stem circumference for domestic consumption, while ring-barking or felling trees before stripping was most appropriated for bark commercialization that implied collection of large quantity of bark mass.

After defining those criteria, an attempt was made to test the effectiveness and appropriateness in applying those strip prescriptions by each harvester in each working group. Three months later, harvesters concluded that, the harvest prescriptions were:

- easily passing and applicable by gatherers, in regard to the labour of stripping with the machete and the time spent to complete bag-loads per trip; 
- profitable as it could yield sufficient bark either for household consumption or for trade;

- sustainable as it would allow tree survival and bark recovery with less impact on plant growth and development.

Thereafter, round discussions within all the working-groups to draw out synthesis and recommendations followed. To end the process, meetings and workshops were organized in the two pilot villages and in other villages in order to discuss and to perform the emerging results with peers, as well as to contribute to the geographical diffusion of these results and recommendations. The peers included community chiefs, harvesters, bark traders, palm wine processors, traditional healers and other members of the village communities. During these meetings, fortunately, local people and gatherers showed real interest in adopting and applying these stripping prescriptions. Unfortunately, the open-access status of natural stands of $G$. lucida has been pointed out as the most vulnerable point in establishing these rules. Therefore, the challenge was to establish responsibilities and enforce rules in applying those harvest prescriptions, in the specific context of G. lucida species governed by an open access regulation. Capitalizing all those findings, the emerging recommended outcomes from this community-based and participatory process included:
- Selectively harvest bark from larger trees available and avoid young individuals;

- Partial debarking $1 / 3$ or $2 / 3$ of the tree circumference to supply bark need for household consumption (medicinal purposes, palm wine additive), while ring-barking or quite willing, felling trees at 1 meter height to ensure sufficient bark mass (per labour days) for commercial proposes; as the stump exhibited a remarkable ability to re-sprout (Figure 3) and therefore, further opportunities to manage coppice growth;

- Repeat harvest on the same tree after a complete bark recovery to the preharvest;

- Regulate the resource-access in wild stands in order to efficiently apply the sustained bark stripping prescriptions as defined during the community-based and participatory survey;

- Design of tree species clonal selection and multiplication with desirable "genetic" characteristics as potential crops for agroforestry;

- Design and implement different planting systems (enrichment planting, small-scale farming and plantations) for G. lucida cultivation.

Table 1: Summary of harvester traditional ecological knowledge about Garcinia lucida.

\begin{tabular}{llll}
\hline $\begin{array}{l}\text { Type of } \\
\text { infor- }\end{array}$ & Characteristics & Traditional ecological knowledge (TEK) & $\begin{array}{l}\text { Concordance } \\
\text { with ecologi- } \\
\text { mation }\end{array}$ \\
& & $\begin{array}{l}\text { cal study rec- } \\
\text { ords }\end{array}$ \\
\hline
\end{tabular}

\begin{tabular}{lll}
\hline $\begin{array}{l}\text { Species } \\
\text { ecology }\end{array}$ & Species identifica- & Local harvesters thought that there were two \\
tion & & Not accurate \\
& & was easily detached from the wood and other \\
& which bark was hardly removed from the \\
& wood
\end{tabular}


Habitat

Hilly mountain sides

Excellent

Species density or

Dense population

Excellent

abundance

Recruitment

Good recruitment

Excellent

Seed predator

Porcupine

Good

\begin{tabular}{|c|c|c|c|}
\hline \multirow{17}{*}{$\begin{array}{l}\text { Bark strip- } \\
\text { ping prac- } \\
\text { tices }\end{array}$} & $\begin{array}{l}\text { How to locate the } \\
\text { resource? }\end{array}$ & $\begin{array}{l}\text { Identification of stands during hunting trips or } \\
\text { by other hunters }\end{array}$ & Excellent \\
\hline & \multirow[t]{2}{*}{ Selection of stand } & 1- distance to resource & Excellent \\
\hline & & 2- abundance of larges trees & Excellent \\
\hline & \multirow{2}{*}{$\begin{array}{l}\text { Criteria to select } \\
\text { trees }\end{array}$} & 1- Bark thickness & Excellent \\
\hline & & $\begin{array}{l}\text { 2- Ability to be removed from wood like } \\
\text { "cassava peel" }\end{array}$ & Some \\
\hline & $\begin{array}{l}\text { Raisons for aban- } \\
\text { doned stand }\end{array}$ & Scarcity of large adult trees with thick bark & Excellent \\
\hline & \multirow[t]{4}{*}{ Stripping practices } & 1- ring-barking & Excellent \\
\hline & & 2- hammering the stem with a stick & Excellent \\
\hline & & 3- peeling off with a machete & Excellent \\
\hline & & 4- felling trees & Excellent \\
\hline & \multirow{7}{*}{$\begin{array}{l}\text { Problems collecting } \\
\text { bark }\end{array}$} & Poor climbing and carrying skills & Excellent \\
\hline & & Ring-barking or felling trees & Excellent \\
\hline & & $\begin{array}{l}\text { Uncontrolled harvest of trees in forests, no } \\
\text { temporal or geographical restriction of harvest }\end{array}$ & Excellent \\
\hline & & Illegal harvesting of trees in cocoa plantation & Excellent \\
\hline & & Non protection of young trees & Excellent \\
\hline & & Non protection of G. lucida stand habitats & Excellent \\
\hline & & $\begin{array}{l}\text { Conflicts related to tree harvest property } \\
\text { rights and G. lucida stand ownership between } \\
\text { neighbouring communities }\end{array}$ & Good \\
\hline \multirow{3}{*}{$\begin{array}{l}\text { Manage- } \\
\text { ment and } \\
\text { conserva- } \\
\text { tion prac- } \\
\text { tices }\end{array}$} & $\begin{array}{l}\text { Bark and seed con- } \\
\text { servation practices }\end{array}$ & $\begin{array}{l}\text { Use of "essok" leaves to conserve bark for 2-3 } \\
\text { weeks }\end{array}$ & \\
\hline & & $\begin{array}{l}\text { Grinding bark and seeds for longer conserva- } \\
\text { tion }\end{array}$ & \\
\hline & Planting trees & $\begin{array}{l}\text { Tree cultivation in Coco-farms with seeds or } \\
\text { seedlings from forests }\end{array}$ & Excellent \\
\hline
\end{tabular}




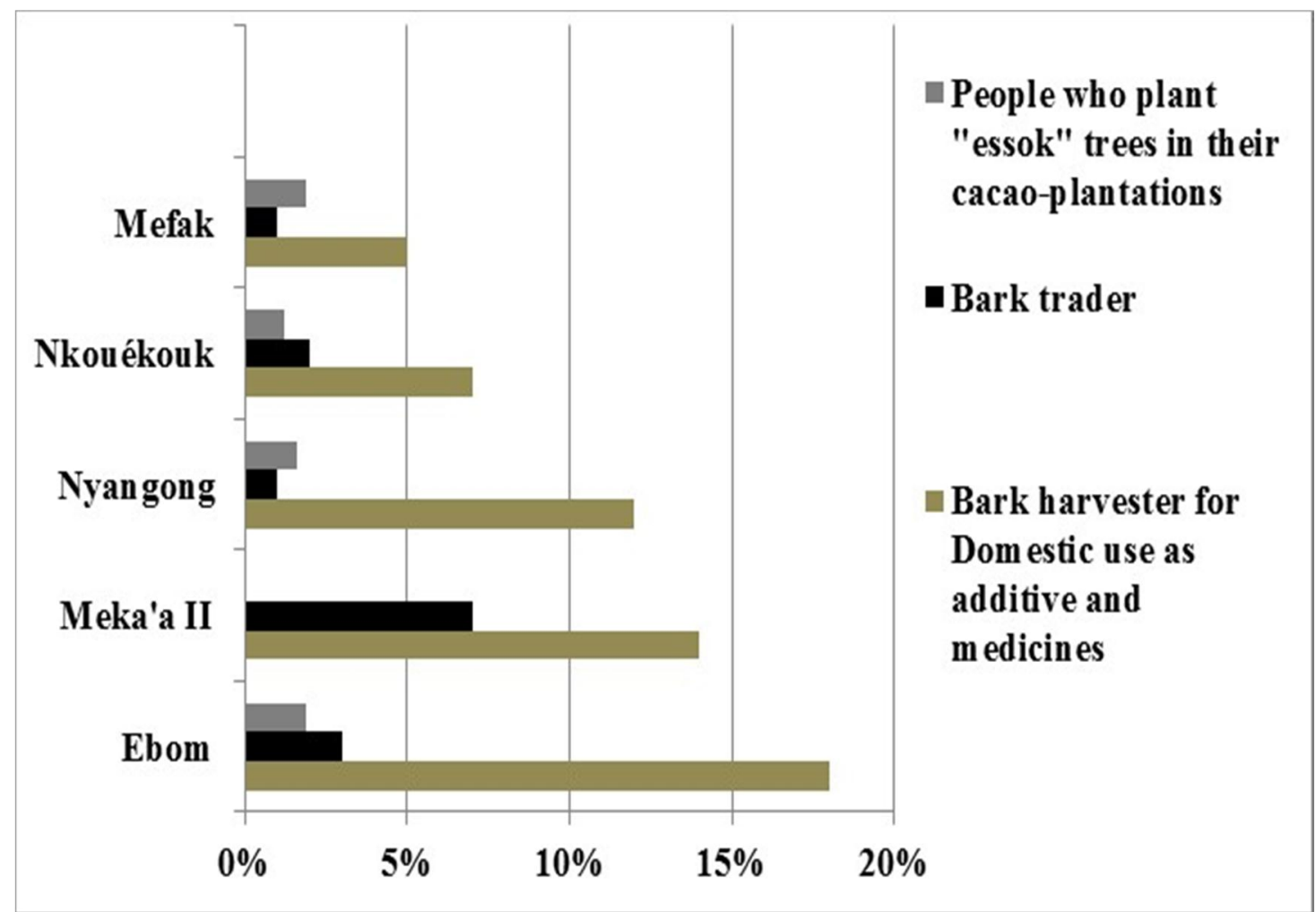

Figure 2: Frequency of local people involved in bark harvesting and planting G. lucida trees in the Bipindi-Loloforf-Akom II region. ( $\mathrm{N}=1601$; Ebom: 411; Meka'a II: 178; Nyangong: 321; Nkouékouk: 425; Mefak: 266).

Table 2: Total and mean number of G. lucida trees stripped and bark mass collected in the BipindiLolodorf-Akom II region (per harvester and per month).

\begin{tabular}{|c|c|c|c|c|c|c|c|c|}
\hline \multicolumn{2}{|c|}{ Bark harvest processing } & \multirow{2}{*}{$\begin{array}{c}\text { Bark } \\
\text { harvester } \\
\text { (n) }\end{array}$} & \multicolumn{2}{|c|}{$\begin{array}{l}\text { Area exploit- } \\
\text { ed (n) }\end{array}$} & \multicolumn{2}{|c|}{$\begin{array}{l}\text { Trees } \\
\text { stripped (n) }\end{array}$} & \multicolumn{2}{|c|}{$\begin{array}{l}\text { Bark mass } \\
\text { stripped (kg) }\end{array}$} \\
\hline & Frequency & & Total & Mean & Total & Mean & Total & Mean \\
\hline \multirow{4}{*}{$\begin{array}{l}\text { For trade in } \\
\text { towns }\end{array}$} & Regularly & 4 & 10 & 3 & 1435 & 72 & 12330 & 617 \\
\hline & Periodically & 6 & 13 & 2 & 833 & 28 & 3870 & 129 \\
\hline & Episodically & 13 & 27 & 2 & 449 & 7 & 1530 & 24 \\
\hline & Sub-total & 23 & 50 & 2 & 2717 & 24 & 17730 & 154 \\
\hline \multirow{5}{*}{$\begin{array}{l}\text { For domestic } \\
\text { use as addi- } \\
\text { tive to palm } \\
\text { wine produc- } \\
\text { tion and } \\
\text { medicines }\end{array}$} & Regularly & 2 & 4 & 2 & 25 & 3 & 45 & 5 \\
\hline & Periodically & 4 & 4 & 1 & 33 & 2 & 45 & 2 \\
\hline & Episodically & 6 & 6 & 1 & 35 & 1 & 90 & 3 \\
\hline & Sub-total & 12 & 14 & 1 & 93 & 2 & 180 & 3 \\
\hline & Total & 35 & 64 & 2 & 2810 & 16 & 17910 & 102 \\
\hline
\end{tabular}




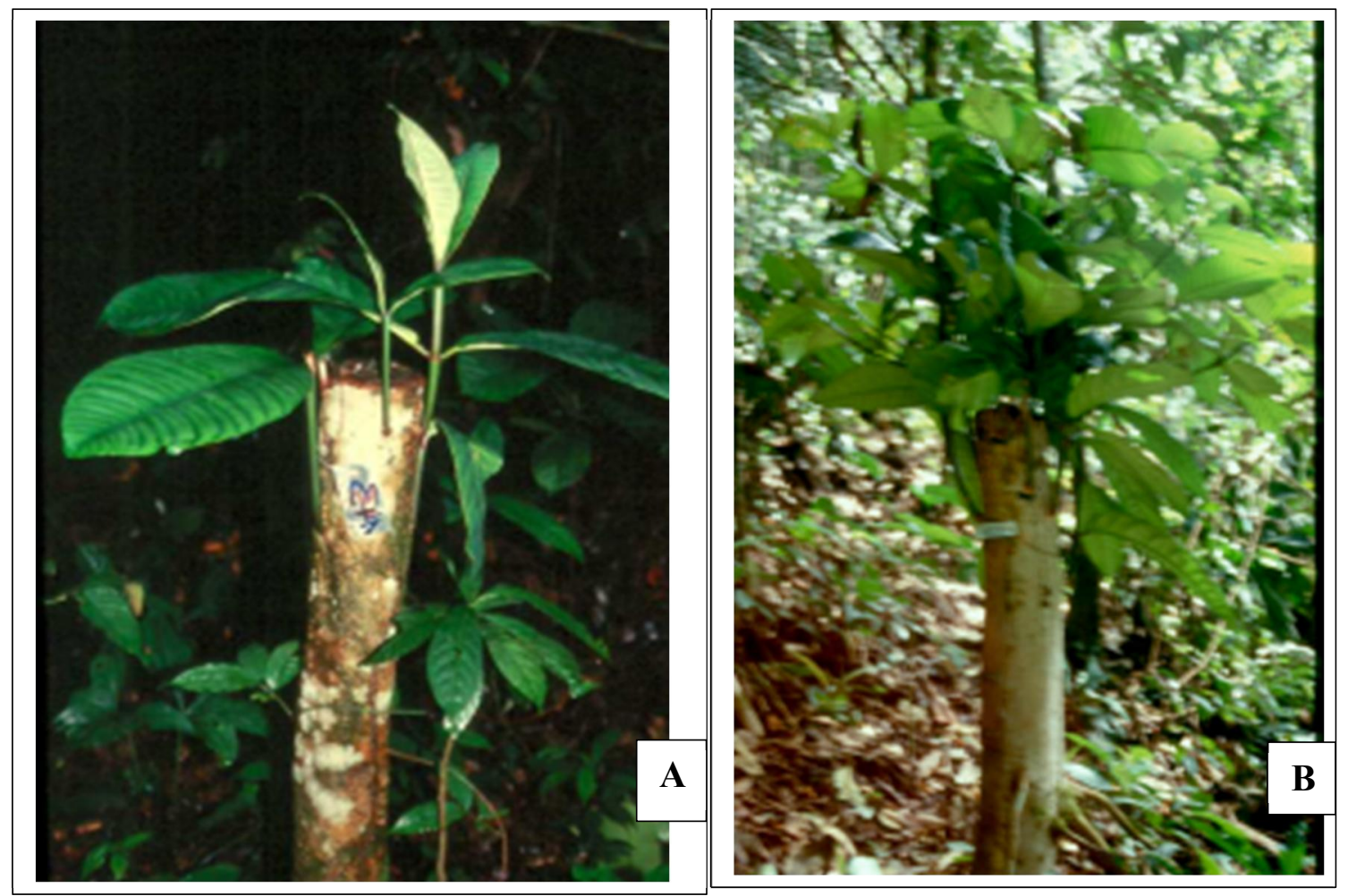

Figure 3: Important development of sprouts by Garcinia lucida stump after felling tree as harvest method. A: mean number of shoots varying from 0 to 12 per stump; B: vigour of shoots after 12 months.

\section{DISCUSSION}

Bark harvesters in the BipindiLolodorf-Akom II region have provided accurate information on habitat, density, recruitment, seed predator of G. lucida species that matched well the information found with ecological studies carried out in parallel. However, there were some gaps and discrepancies between the two types of knowledge, most notably with the fact that harvesters identified two types of "essok" based on the ability of bark to be more or less easily removed from wood. In fact, this information has later led to found that there exists only one species of G. lucida, accurately identified by trained botanists (Guedje et al., 2017), from which, bark was easily removed from wood like "cassava peel" when trees were characterized physiologically by the existence or predominance of an upward sap flow, due to good water supply in trees and consequently on soil, given the fact that the species was mainly found in hilly mountain sides. On the contrary, bark was hardly removed when trees were characterized by the predominance of a downward sap flow (Guedje et al., 2016). Though, TEK have provided useful information of management significance such as the species geographical distribution which have been used to identify and locate all the stands needed for the ecological studies, thereby it highlighted its potential as important tools that could serve in a participatory resource distribution mapping and management process, and be easily integrated into forest management planning and regulations. In addition, TEK have been useful in the assessment of bark harvest practices and defining criteria for sustainable harvesting and species management. Indeed, 
as stated by Rist et al. (2010), a significant benefit of combining the use of TEK and conventional scientific data in management may be that the two sources of information might be used to check against the other. This approach provides more robust conclusions upon which to base management.

Bark traders were stakeholder who had stripped the highest number of trees and collected the larger quantity of bark wet mass compared with those who collected wet bark for medicinal purposes or additive for palm wine and traditional liquor processing at the village-level; highlighting that there is a need to distinguish between rural subsistence use performed by traditional health practitioners or palm wine processors, and commercial trade between rural areas and urban markets. According to Geldenhuy (2011), plant material for the commercial trade is collected by harvesters who may have very little knowledge of the species and good practices. The harvesting of G. lucida bark has been increasing in South Cameroon since the devaluation of the CFA Franc in January 1994 that raised the price of industrial beers and liquors, and consequently increasing demand for palm wine and local liquor "Odontol" made with G. lucida bark. Some studies have reported that the global demand for bark was steadily growing and has caused some $G$. lucida stands and trees, very sensitive to high levels of harvest, to become threatened, as well as the occurrence of many conflicts related to the open-access status of G. lucida forest stands and the land-forest and resource tenure and ownership in the Bipindi-LolodorfAkom II area in South Cameroon (Ndoye et al., 2001; Djaligue, 2007; Guedje et al., 2016). The challenge will be therefore to support traditional subsistence bark use and control sustainable levels for commercial bark use, but, lack of proactive natural resource management initiatives, especially in response to expanding markets such as phytomedicine production prospects, often leads to biological and ultimately economic impoverishment (Nepstad et al., 1992). Active management programs may help to counter this trend and rescue natural resources from being undervalued and thus overexploited (Panayotou and Ashton, 1993). According to Peters (1996), to be effective and successful however, active management for medicinal species needs to be based not only on sound biological data, but also on socio-economic information as it has been shown for G. lucida species in the present approach.

In regard to this, the community-based and participatory monitoring and evaluation of bark stripping practices have enabled local gatherers to jointly discuss about criteria for an efficient and sustainable harvesting system, based on the stripped trees tested and observed and using their own knowledge about the resource ecology. Further to the discussions, they have tested the applicability of this harvesting system and formulated recommendations and suggestions aiming at performing the harvest system, such as selectively harvest bark from larger trees and repeat harvesting on the same tree after a complete bark recovery. They have considered that harvesting $1 / 3$ or $2 / 3$ of the tree circumference could supply the bark need for household consumption, while ring-barked or felling trees at 1 meter height may easily provide sufficient quantities (per labour days) for commercial proposes. Fortunately, local gatherers showed real interest in applying those sustainable stripping practices during the participatory survey and evaluation. Unfortunately, the open-access of natural stands of G. lucida has been pointed out as the most vulnerable point of applying such prescriptions. With regard to this, the open access and the increased conflicts reported from the Bipindi-Lolodorf-Akom II area, indicated that the species seems to be regarded as a common property resource (CPR), and that there will be lack of appropriate enforcement in some instances when rules would be established (Mukamuri and Kozanayi, 2014). As stated by Romero et al. (2014), if wild resource is to be managed as a $\mathrm{CPR}$, then the responsibility of its management should go to the local communities and their institutions, with the collaboration of the governmental institutions. Efforts to sustain the resource could be 
achieved within a framework of adaptive management, which has proved successful in several other situations (Walters and HolUng, 1990). The delegation of the right to manage bark resources to the communities needs to be accompanied by the acceptance of associated responsibilities as well. Several authors have identified this empowerment as a condition to obtain effective commitment from local stakeholders to conservation and sustainable management, particularly in those situations where there is insecurity of tenure (Lynch and Alcorn, 1994; Ham and Theron, 1998).

There are relatively few studies on the approaches to define impacts of harvesting and guidelines for promoting ecological sustainability, together with participatory resource management (Peters 1996; Romero et al., 2014; Baldauf et al., 2015). Consequently, as stated by Alexander and McLain (2001), Shackleton et al. (2015), many authorities adopt a precautionary approach rather than an adaptive one. The absence of clear guidelines is largely a result of the daunting multitude of resource species for which in-depth studies are required (Ticktin and Shackleton, 2011). Moreover, this challenge is magnified by the need to further understand how harvesting impacts and responses differ in different locations and contexts even for the same species (Gaoue and Ticktin, 2010). Consequently, management of most wild resources is based on limited and frequently untested scientific assumptions and knowledge of the species autecology and its response to harvesting. Whilst there is undoubtedly an immense wealth of local ecological knowledge about resource species and their responses to various factors (Gaoue and Ticktin, 2009; Youn, 2009; Mwende Maweu, 2011), including harvesting, very little of this has been codified and is therefore frequently overlooked by most formal forest or conservation management authorities (Rist et al., 2010). Regarding these findings, the results of this study have direct bearing on attempts towards sustainable resource use and adaptive management incorporating current ecological knowledge into participatory forest and resource management planning and regulations. According to Harisha et al. (2016), numerous studies reveal that local knowledge derived from long-term naturesociety interactions have been extremely useful in validating scientific hypothesis and suggesting new research directions.

\section{Conclusion}

TEK have provided useful information on the species geographical distribution that could serve as important tools in resource mapping and management. Based on the harvest practices experimental records and using TEK, bark gatherers have recommended a strip of $1 / 3$ or $2 / 3$ of tree circumference, by peeling off bark using machete, for household consumption; or ring-barked or felling trees for commercial proposes; a selection of larger trees and a repeat harvest on the same tree after complete bark recovery. The combined potential of TEK and scientific knowledge should be harnessed to enhance the environment and human well-being. Therefore, there is an essential need for empowerment and self-motivation among local communities, in understanding the status and scope of TEK in bio-resource management. The participation of local people and their knowledge in the process of sustainable development should be recognized and widely used.

\section{COMPETING INTERESTS}

The authors declare that they have no competing interests.

\section{AUTHORS' CONTRIBUTIONS \\ NMG has made substantial contributions to conception and design, acquisition of data, analysis and interpretation of data, drafting the manuscript and revising it critically. FT has been involved in drafting the manuscript. NT and ON have participated in the study design and given final approval of the version to be published.}

\section{ACKNOWLEDGMENTS}

We are deeply grateful to the bark harvesters and the communities of Nkouékouk, Nyangong, Meka'a II and Mefak 
villages (South Cameroon), who generously shared their traditional knowledge with us and participated with enthusiasm in the study. We also thank the anonymous reviewers for their precious comments.

\section{REFERENCES}

Alexander SJ, McLain RJ. 2001. An overview of non-timber forest products in the United States today. J. Sustainable Forestry, 13: 59-66. DOI: http://dx.doi.org/10.1300/J091v13n03_0 5

Baldauf C, dos Santos FAM. 2014. The effect of management systems and ecosystem types on bark regeneration in Himatanthus drasticus (Apocynaceae): recommendations for sustainable harvesting. Env. Monit. Assessm., 186: 349-359. DOI: 10.1007/s10661-0133378-X

Baldauf C, Corrêa CE, Ciampi-Guillardi M, Sfair JC, Pessoa DD, Oliveira RCF, Machado MF, Milfont CID, Sunderland TCH, dos Santos FA. 2015. Moving from the ecological sustainability to the participatory management of janaguba (Himatanthus drasticus; Apocynaceae). In Ecological Sustainability for Nontimber Forest Products: Dynamics and Case Studies of Harvesting, Shackleton CM, Pandey AK, Ticktin T (eds). Routledge: Abingdon, Oxon OX14 4RN and New York; 144 - 162. DOI: http://www.routledge.com/books/series/ ECPPIC/

Chatterjee D, Sarkar R. 2016. Bio-resource Utilization for Food and Medicine: A Case Study of a Primitive Tribal Group of Jharkhand, India. Int. J. Mod. Anthrop., 9: 21-49. DOI: http://dx.doi.org/10.4314/ijma.v1i9.2

Costa A, Nunes LC, Spiecker H, Graça J. 2015. Insights into the responsiveness of Cork Oak (Quercus suber L.) to bark harvesting. Eco. Bot., 69(2): 171-184. DOI: $10.1007 / \mathrm{s} 12231-015-9305-\mathrm{z}$

Cunningham AB. 2014a. The Ethnobotany, Use, and Sustainable Harvest of Bark: A Review. In Bark : Use, Management, and Commerce in Africa, Cunningham AB, Campbell BM, Luckert MK (eds). Advances in Economic Botany Vol. 17, The New York Botanical Garden Press: New York; 27-55.

Cunningham AB. 2014b. A global footprint on Africa and Madagascar: a review of international trade in Prunus africana (Rosaceae) bark. In Bark: Use, Management, and Commerce in Africa, Cunningham AB, Campbell BM, Luckert MK (eds). Advances in Economic Botany Vol. 17, The New York Botanical Garden Press: New York; 153-177.

Delvaux C, Sinsin B, Darchambeau F, Van Damme P. 2009. Recovery from bark harvesting of 12 medicinal tree species in Benin, West Africa. J. Applied Ecology, 46(3): 703-712. DOI: 10.1111/j.1365-2664.2009.01639.x

Djaligue Y. 2007. Déforestation : menace sur l'«Essok» - Dossier. Bubinga, 122: 5-7.

Gaoue OG, Ticktin T. 2009. Fulani knowledge of the ecological impacts of Khaya senegalensis (Meliaceae) foliage harvest in Benin and its implications for sustainable harvest. Eco. Botany, 63: 256-270. DOI: 10.1007/s12231-0099091-6

Gaoue OG, Ticktin T. 2010. Effects of harvest of non-timber forest products and ecological differences between sites on the demography of African mahogany. Conserv. Biology, 24: 605-614. DOI: 10.1111/j.1523-1739.2009.01345.x

Geldenhuys CJ, Syampungani S, Meke GS, Vermeulen WJ. 2007. Response of different species to bark harvesting for traditional medicine in Southern Africa. In Multiple Use Management of Natural Forests and Woodlands: Policy Refinement and Scientific Progress, Bester JJ, Seydack AHW, Vorster T, Van der Merwe IJ, Dzivhani S (eds). Department of Water Affairs and Forestry: Pretoria; 55-62.

Geldenhuys CJ. 2011. Sustainable management of bark harvesting for 
traditional medicine. DOI: http://saforestryonline.co.za/articles/

Guedje NM, Zuidema PA, During H, Foahom B, Lejoly J. 2007. Tree bark as a nontimber forest product: The effect of bark collection on population structure and dynamics of Garcinia lucida Vesque. Forest Ecol. Manag., 240: 1-12. DOI: https://doi.org/10.1016/j.foreco.2006.09. 029

Guedje NM, Tchamou N, Lejoly J. 2016. Tree response to bark harvest: the case of a medicinal species, Garcinia lucida, as source of raw materials for plant-based drug development. J. Appl. Biosci, 99: 9476-9491. DOI: 10.4314/jab.v99i1.13

Guedje NM, Tadjouteu F, Onana JM, Nnanga Nga E, Ndoye O. 2017. Garcinia lucida Vesque (Clusiaceae): from traditional uses to pharmacopeic monograph for an emerging local plant-based drug development. J. Appl. Biosci., 109: 10594-10608. DOI : http://dx.doi.org/10.4314/jab.v109i1.4

Ham C, Theron F. 1998. Community Forestry

- Project implementation through communities as a whole or through interest groups? South. African Forestry J., 181: 45-49. http://dx.doi.org/10.1080/10295925.1998 .9631180

Harisha RP, Padmavathy S, Nagaraja BC. 2016. Traditional ecological knowledge (TEK) and its importance in South India: perspective from local communities. $A$. Ecol. Envir. Research, 14(1): 311-326. DOI: http://dx.doi.org/10.15666/aeer/1401_31 1326

Ingram $\mathrm{V}$, Loo J, Vinceti $\mathrm{B}$, Dawson I, Muchugi A, Duminil J, Awono A, Asaah E, Tchoundjeu Z. 2015. Ensuring the future of the pygeum tree (Prunus africana) - Briefing on Prunus africana cultivation and harvesting. http://www.researchgate.net/publication/ 277553809

Kemppainen K, Siika-aho M, Pattathil S, Giovando S, Kruus K. 2014. Spruce bark as an industrial source of condensed tannins and non-cellulosic sugars. Indust. Crops Products, 52:158-168. DOI: https://doi.org/10.1016/j.indcrop.2013.10 .009

Lynch JO, Alcom JB. 1994. Tenurial rights and community-based conservation. In Natural Connections: Perspectives in community-based conservation, Western D, Wright RM, Strum SC (eds). Island Press: Washington DC; 373-392.

Mariot A, Mantovani A, Reis MS. 2014. Bark Harvesting Systems of Drimys brasiliensis Miers in the Brazilian Atlantic Rainforest. Anais da Academia Brasileira de Ciências, 86(3): 1315$1326 . \quad$ DOI : http://dx.doi.org/10.1590/00013765201420130180

Mukamuri BB, Kozanayi W. 2014. Commercialization and institutional arrangements involving tree species harvested for bark by smallholder farmers in Zimbabwe. In Bark: Use, Management, and Commerce In Africa, Cunningham AB, Campbell BM, Luckert MK (eds). Advances in Economic Botany Vol. 17, The New York Botanical Garden Press: New York; 247-254.

Mwende Maweu J. 2011. Indigenous Ecological Knowledge and Modern Western Ecological Knowledge: Complementary, not Contradictory. Thought and Practice: J. Philosophi. Asso. Kenya (PAK), New Series, 3(2): 35-47.

DOI: http://ajol.info/index.php/tp/index

Ndoye O, Ruiz-Perez M, Eyebe A. 2001. NTFP markets and potential degradation of forest resources in Cameroon: the case of Garcinia lucida. Europ. Trop. Forest Research Network News, 32: 44-45. DOI: http://www.cifor.org/nc/onlinelibrary/browse/viewpublication/publication/1050.html

Nepstad DC, Brown F, Luz L, Alechandra A, Viana V. 1992. Biotic impoverishment of Amazonian forests by rubber-tappers, loggers and cattle ranchers. Ad. Econ. 
Botany, 9: 1-14. URL: http://www.nal.usda.gov/

Nguedia AJC, Shey ND. 2014. African medicinal plant derived products as therapeutic arsenals against multidrug resistant microorganisms. J. Pharmacog. Phytoth., 6(5): 59-69. DOI: 10.5897/JPP2013.0322

Panayotou T, Ashton P. 1992. Not by timber alone: the case of multiple use management of tropical forests. Island Press: Covelo.

Pandey AK. 2015. Sustainable bark harvesting of important medicinal tree species, India. In Ecological Sustainability for Non-timber Forest Products: Dynamics and Case Studies of Harvesting, Shackleton CM, Pandey AK, Ticktin T (eds). Routledge: Abingdon, Oxon OX14 4RN and New York; 163-178. DOI: http://www.routledge.com/books/series/ ECPPIC/

Persoon GA. 2006. Co-management of natural resources: some themes and unresolved issues. In Community-Based Conservation of Natural Resources in Dry and Sub-humid Savannas. Proceedings of the Second RNSCC International Seminar, Maroua, Cameroon, Mayaka TB, Fotsing E, de Iongh $\mathrm{H}$, Loth $\mathrm{P}$ (eds). RNSCC, CEDC and CML: Leiden; 9-21.

Peters CM. 1996. The ecology and management of non-timber forest resources. World Bank Technical Paper $\mathrm{N}^{\circ}$ 322: Washington DC. DOI: http://www.researchgate.net/publication/ 238066719

Rist L, Uma Shaanker R, Milner-Gulland EJ, Ghazoul J. 2010. The use of traditional ecological knowledge in forest management: an example from India. Ecol. Soc., 15(1): 3. DOI : http://www.ecologyandsociety.org/vol15 /iss1/art3/

Romero C, Dovie DBK, Gambiza J, Luoga E, Schmitt S, Grundy I. 2014. Effets of Commercial Bark Harvesting on
Adansonia digitata (Baobab) in the Save-Ozi Valley, Zimbabwe, with Considerations for its Management. In Bark: Use, Management, and Commerce In Africa, Cunningham AB, Campbell BM, Luckert MK (eds). Advances in Economic Botany Vol. 17, The New York Botanical Garden Press: New York; 95-114.

Senkoro AM, Barbosa FM, Moiane SF, Albano G, de Barros AIR. 2014. Bark Stripping from forest tree species in Madjadjane, Southern Mozambique: medicinal uses and implications for conservation. Natural Resources, 5: 192199.

DOI: http://dx.doi.org/10.4236/nr.2014.55018

Shackleton CM, Ticktin T, Pandey AK. 2015. Introduction: the need to understand the ecological sustainability of non-timber forest products harvesting systems. In Ecological Sustainability for Non-timber Forest Products: Dynamics and Case Studies of Harvesting, Shackleton CM, Pandey AK, Ticktin T (eds). Routledge: Abingdon, Oxon OX14 and New York; 3-11.

DOI: http://www.routledge.com/books/series/ ECPPIC/

Ticktin T, Shackleton CM. 2011. Harvesting non-timber forest products sustainably: opportunities and challenges. In NonTimber Forest Products in the Global Context, Shackleton S, Shackleton C, Shanley P (eds). Springer: Heidelberg; 149-70.

Walters C, Holbng CS. 1990. Large scale management experiments and learning by doing. Ecology, 71: 2060-2068. DOI: http://www.jstor.org/stable/1938620

Youn YC. 2009. Use of forest resources, traditional forest-related knowledge and livelihood of forest dependent communities: cases in South Korea. Forest Ecol. Manag., 257: 2027-2034. DOI: https://doi.org/10.1016/j.foreco.2009.01. 054 